\title{
ТЕОРЕТИЧНІ ТА ЗАКОНОДАВЧІ ОСОБЛИВОСТІ ЗАСТОСУВАННЯ ФОРМ ПРОГРЕСИВНОЇ СИСТЕМИ ВИКОНАННЯ ТА ВІДБУВАННЯ ПОКАРАННЯ У ВИГЛЯДІ ПОЗБАВЛЕННЯ ВОЛІ
}

Гритенко О. А.

\begin{abstract}
У статті розглядаються теоретичні та правові особливості конструкції, специфічність підстав застосування, правові наслідки реалізаціі форм прогресивної системи виконання та відбування поканання у вигляді позбавлення волі. А також здійснюється аналіз чинних кримінально-виконавчих норм, в яких безпосередньо відтворюється прогресивна система виконання та відбування покарання у вигляді позбавлення волі. Окрема увага приділена формам прогресивної системи виконання та відбування покарання у вигляді позбавлення волі, таким як зміна умов утримання в межах однієї кримінально-виконавчої установи, а також переведення з однієї установи до іншої. Розкриваються окремі елементи прогресивної системи виконання та відбування покарання, зокрема право на поліпшені умови відбування покарання. Визначено, що історично саме з такою формою прогресивної системи, як зміна утримання засуджених в межах однієї установи, пов'язувалися їі зміст та сутність. В окремих випадках цю форму навіть ототожнювали із прогресивною системою як такою. Підтверджується те, що через інститут зміни умов утримання засуджених в межах однієї установи здійснюється лише узагальнене сприйняття того, що в дійсності відбувається із засудженими. Проте змістовне та сутнісне наповнення цієї форми, механізм їі реалізації, позитивні та негативні аспекти законодавчих формулювань - відтворюються в конкретних елементах цього інституту. Адже він має свою підсистему, елементи більш нижчого рівня, які вирізняються певною специфічністю змісту правових положень та послідовністю їхньої реалізації. Доведено, що найважливіші властивості прогресивної системи відтворюються в порядку та умовах розміщення засуджених в певних дільницях однієї установи, підставах для переведення з однієі дільниці в іншу. Визначено, що зміна умов тримання засуджених шляхом переведення до іншої установи історично вважалася головним, найтиповішим виявом прогресивноі системи. Проте саме ия форма історично розглядалася як така, що об'єктивно містила в собі потенційні негативні властивості, які зумовлювалися психологічними закономірностями впливу на особу суттєвих змін їі соціального статусу та умов їі життєдіяльності.
\end{abstract}

Ключові слова: виконання покарання, відбування пока рання, форми прогресивної системи, елементи прогресивної системи, засуджені особи, правовой статус.

В статье рассматриваются теоретические и правовые особенности конструкции, специфичность оснований применения, правовые последствия реализации форм прогрессивной системы исполнения и отбывания поканання в виде лишения свободы. А также осуществляется анализ действующих уголовно-исполнительных норм, в которых непосредственно воспроизводится прогрессивная система исполнения и отбывания наказания в виде лишения свободы. Особое внимание уделено формам прогрессивной системы исполнения и отбывания наказания в виде лише-

(ㄷ Гритенко О. А., 2020 ния свободы, таким как изменение условий содержания в пределах одной уголовно-исполнительного учреждения, а также перевод из одного учреждения в другое. Раскрываются отдельные элементы прогрессивной системы исполнения и отбывания наказания, в частности право на улучшенные условия отбывания наказания. Определено, что исторически именно с такой формой прогрессивной системы, как изменение содержания осужденных в пределах одного учреждения, связаны ее содержание и сущность. В отдельных случаях эту форму даже отождествляли с прогрессивной системой как таковой. Подтверждается то, что через институт изменения условий содержания осужденных в пределах одного учреждения осуществляется только обобщенное восприятие того, что в действительности происходит с осужденными. Однако содержательное и сущностное наполнение этой формы, механизм ее реализации, положительные и отрицательные аспекты законодательных формулировок - воспроизводятся в конкретных элементах этого института. Ведь он имеет свою подсистему, элементы более низкого уровня, которые отличаются определенной спецификой содержания правовых положений и последовательностью их реализации. Доказано, что важнейшие свойства прогрессивной системы воспроизводятся в порядке и условиях размещения осужденных в определенных участках одного учреждения, основаниях для перевода с одного участка в другой. Определено, что изменение условий содержания осужденных путем перевода в другое учреждение исторически считалась главным, типичным проявлением прогрессивной системы. Однако именно эта форма исторически рассматривалась как такая, которая объективно содержала в себе потенциальные негативные свойства, которые оговаривались психологическими закономерностями влияния на личность существенных изменений ее социального статуса и условий ее жизнедеятельности.

Ключевые слова: исполнение наказания, наказание, формы прогрессивной системы, элементы прогрессивной системы, осужденные лица, правовой статус.

Hrytenko 0. A. Theoretical and legislative features of application of progressive system forms of execution and serving by custody

The article considers the theoretical and legal features of construction, specifics of its application, legal consequences of implementation of progressive system forms of execution and serving a sentence by custody. It is carried out also the analysis of the current criminal-executive norms in which the progressive system of execution and serving a sentence is directly reproduced. Particular attention is paid to the progressive system forms of execution and serving a sentence by custody, such as changing the detention conditions within one penitentiary institution, as well as transferring from one institution to another. Some elements of the progressive system of execution and serving a sentence are revealed, in particular, the right to improved conditions of serving a sentence. It has been determined that historically, its content and essence have been asso- 
ciated with such a form of progressive system as the change of detention of convicts within one institution. In some cases, this form was even identified with the progressive system as such one. It is confirmed that through the institution of changing the detention conditions of convicts within one institution, only a generalized perception of what is really happening to convicts is carried out. However, the substantive and essential content of this form, mechanism of its implementation, positive and negative aspects of legislative wording are reproduced in specific elements of this institution. After all, it has its own subsystem, elements of a lower level, which are characterized by a certain specificity of legal provisions' content and sequence of their implementation. It is proved that the most important properties of the progressive system are reproduced in order and conditions of convicts in certain sections one institution, grounds for transfer from one section to another one. It has been determined that changing the detention conditions of convicts by transferring them to another institution has historically been considered the main, most typical manifestation of progressive system. However, this form has historically been considered as one that objectively contained potential negative properties, which were determined by psychological patterns of influence on a person of significant changes in hislher social status and living conditions.

Key words: execution of punishment, serving a sentence, forms of progressive system, elements of progressive system, convicted, legal status.

Постановка проблеми. Дослідження теоретичних та правових аспектів щодо особливостей правової конструкції кожної форми, специфічність підстав застосування, правові наслідки реалізації та аналіз чинних кримінально-виконавчих норм, в яких безпосередньо відтворюється прогресивна система виконання та відбування покарання у вигляді позбавлення волі, $\epsilon$ важливим напрямком дослідження. Проте ці проблеми заслуговують на окреме поглиблене дослідження з урахуванням сучасних вітчизняних та міжнародних тенденцій реформування кримінально-виконавчого законодавства, і $є$ предметом цього дослідження.

Однією з найбільш застосовуваних у правозастосуванні форм прогресивної системи виконання та відбування покарання у вигляді позбавлення волі $\epsilon$ зміна умов утримання в межах однієї кримінально-виконавчої установи. Переведення засудженого в межах однієї виправної колонії небезпідставно вважають історично першою та головною формою (субінститутом) прогресивної системи виконання покарання у вигляді позбавлення волі на певний строк [6, с. 9]. Заслуговують на особливу увагу ті доктринальні положення, в яких відтворюється проблема співвідношення кримінально-виконавчого інституту «зміни умов тримання засуджених» та суто «прогресивної системи». Розуміючи під першим сукупність взаємопов'язаних і взаємодіючих норм та правил, які визначають порядок зміни умов тримання засуджених до позбавлення волі, відокремлюючи його від системи заходів заохочення і стягнення, - пропонується розглядати цей інститут як підсистему прогресивної системи відбування покарання або ж як самостійну систему нижчого рівня. Відповідно, маємо погодитися з тим, що інститут зміни умов тримання не може бути тотожнім прогресивній системі, оскільки він $\epsilon$ іï елементом [7, с. 620, 637].

Виклад основного матеріалу. Найтиповішими елементами цієї системи є інститути: переведення в різні дільниці однієї виправної установи; переведення на поліпшені умови тримання; заходи заохочення (стягнення). Відкритим до сьогодні залишається питання щодо віднесення до цих елементів право на переміщення поза межами установи без конвою, право мешкання жінки, яка є вагітною або ж має дитину віком до трьох років, за межами установи тощо.

Безумовним $\epsilon$ те, що ефективність виконання та відбування покарання у вигляді позбавлення волі на певний строк суттєво залежить від чіткості та узгодженості законодавчих визначень та формулювань щодо категорій засуджених осіб, які мають перебувати в різних структурних підрозділах - дільницях однієї кримінально-виконавчої установи (карантину, діагностики і розподілу; ресоціалізації; посиленого контролю; соціальної реабілітації; соціальної адаптації), від обсягу правообмежень, які $\epsilon$ сутністю та змістом режимних вимог під час перебування засуджених у цих дільницях.

Саме ті відмінності, які характеризують дільниці за колом засуджених осіб, які можуть там перебувати, відтворюються в дозволеному обсязі прав, законних інтересів, у порядку відбування покарання (режимних вимогах), - $є$ суттєвим підтвердженням того, що найпоширеною формою змін умов тримання в межах установи $€$ переведення засуджених із одної дільниці в іншу з більшим обсягом пільг (або ж навпаки). Так, стимулююче значення переведення до дільниці ресоціалізації посилюються тим, що (крім іншого) перебування в ній надає право на поліпшені умови тримання; переведення в дільницю соціальної реабілітації передбачає практично вільний спосіб мешкання за межами установи тощо.

У зазначених вище наукових дослідженнях, присвячених прогресивній системі, їі форми аналізуються зазвичай на рівні оцінки змін умов тримання засуджених у межах однієї установи, і доволі рідко це питання поглиблюється за рахунок аналізу такого підсистемного iї елементу, як право на поліпшені умови відбування покарання.

Виключенням $є$ спеціальні публікації, де це питання $\epsilon$ безпосередньо предметом дослідження. Так, В.Я. Конопельский пропонує розглядати поліпшення умов відбування покарання як у широкому значенні (охоплення будь-яких змін у правовому статусі засудженої особи в бік пом'якшення режимних вимог), так і у вузькому (спеціальному) значенні - як застосування за наявності формальних та матеріальних підстав у порядку заохочення такого заходу, як переведення на поліпшені умови тримання [5, с. 54]. Пропонується головне призначення поліпшених умов (у вузькому, спеціальному розумінні) вбачати у стимулюванні правослухняної поведінки засуджених у місцях позбавлення волі, стабілізації обстановки в установах з виконання покарань, відновленні соціально корисних зв' язків засуджених із зовнішнім світом, зміцненні їхнього здоров'я [9, с. 17].

Проте типовою ознакою більшості розглянутих нами досліджень із питань застосування поліпшених умов $\epsilon$ те, що в них наголошується на тому, що інститут не має належного заохочувального значення; засуджені не надають належного значення цим умовам, оскільки зміни їхнього правового статусу незначні, а отже, не можуть зацікавити засуджених, стати дієвою перспективою у виправленні та ресоціалізації засуджених [3, с. $24 ; 5$, с. $55 ; 9$, с. $17 ; 13$, с. 85$]$ 
Зокрема, щодо останнього зауваження, то дослідження В.О. Меркуловою практики правозастосування даного елементу прогресивної системи виконання покарання в жіночих виправних установах протягом тривалого часу надали підстави дійти висновку щодо того, що лише незначна частина засуджених жінок могла скористатися пільговими умовами в межах закладу. Був зроблений важливий висновок щодо того, що відсутність чинного стимулюючого впливу, тривалість терміну до можливого застосування пільг спричиняли байдуже ставлення засуджених жінок до факту переведення на поліпшені умови утримання, до поцінування їхньої поведінки адміністрацією [8, с. 208-210].

Відповідно, закономірним $\epsilon$ те, що із приводу саме поліпшених умов тримання в ізоляції з пострадянського часу до сьогодні точаться наукові дискусії стосовно кожної ії складової частини: матеріальних та формальних підстав застосування; обсягу та характеру пільг, що $\epsilon$ змістом цих умов та відповідності їх міжнародно-правовим стандартам; доцільності переведення на ці умови саме в дільниці ресоціалізації; співвідношення із базовими (початковими) правообмеженнями тощо. Той факт, що ці питання $\epsilon$ актуальними до сьогодні, підтверджує складний та суперечливий шлях реформування законодавства в цій частині.

Тож слід поглянути на цей суто кримінально-виконавчий інститут із позицій посилення його заохочувального (стимулюючого) значення на першому етапі перебування засудженого в місцях позбавлення волі, коли доволі важливим, але складним завданням установ із виконання покарання $\epsilon$ започаткування позитивних змін у свідомості засудженої особи, створення психологічної основи для формування власного інтересу (бажання) виправитися достроково.

Окремою підсистемою зміни умов тримання засуджених в умовах однієї установи $\epsilon$ інститут заходів заохочення та стягнення. Маємо зупинитися на першому. У Главі 19 міститься доволі цікава за редакцією та порядком викладення нормативно-правового змісту ст. 130 КВК «Заходи заохочення, що застосовуються до осіб, позбавлених волі». Якщо відокремити дві новели в даній нормі, які відтворюються у віднесенні до заходів заохочення переведення на поліпшені умови тримання та надання дозволу особам, які тримаються в дільниці, соціальної реабілітації виправних колоній мінімального рівня безпеки із загальними умовами тримання та середнього рівня безпеки, права на виїзд за межі колонії з метою відвідування рідних, - то маємо зазначити, що в цій нормі визначаються матеріальні підстави застосування окремих заохочувальних заходів, які мають разовий характер, не залежать від терміну відбутого строку, стосуються усіх періодів перебування засудженого в ізоляції (від першого дня до останнього), не залежать від того, в якій дільниці перебуває засуджена особа. А отже, $є$ складовою частиною як первинного (базового) правового стану засудженої особи, так і всіх інших етапів перебування в місцях позбавлення волі. Від засуджених вимагається лише виконувати обов'язки, дотримуватися правил поведінки (встановлених КВК та Правилами внутрішнього розпорядку колонії), правил трудового розпорядку, вимог безпеки.

У пострадянський час типовою була позиція щодо відокремлення заходів заохочення та стягнення (як одиничної реакції на хороший чи поганий вчинок) та більш тривалі зміни умов тримання у виправній установі [11, с. 162].

Проте і сьогодні в доктрині права пропонується поділити усі заохочувальні заходи на дві групи: одноразові заходи заохочення, які надають можливість засудженим морально та матеріально поліпшити своє становище на незначний проміжок часу, коли саме реалізується право на отримання додаткових пільг на підставі сумлінної поведінки, ставлення до праці та навчання, активну участь в самодіяльних організаціях; та заходів заохочення, які спроможні суттєво та на більш тривалий час змінити правове положення засудженого за наявності формальних (відбуття певного строку покарання) та матеріальних (певний ступінь виправлення) умов [3, с. $22 ; 10$, с. 66-68].

Проте не пропонується шлях вирішення цього питання, яке безпосередньо пов'язане з удосконаленням прогресивної системи як такої. Як на наш погляд, то перелік заходів заохочення у чинний спосіб не сприятиме чіткості та системності різних форм (елементів) прогресивної системи. 3 одного боку, сьогодні вже загальновизнаним $\epsilon$ той факт, що правослухняна поведінка засудженого, власний осуд вчиненого, соціальна адаптація $€$ можливими лише в разі комплексного застосування заходів примусу та заохочення. Їх дієве поєднання спроможне закріпити правослухняну поведінку, сприятиме добровільному й свідомому відмовленню засудженого від подальшої антисоціальної поведінки (від вчинення правопорушень), ефективній реалізації соціально-відновлювальної функції покарання на стадії його виконання. Саме такий підхід до сприйняття значення чинної системи заходів заохочення та стягнення дозволяє розглянути ці інститути в межах прогресивної системи виконання та відбування покарання у вигляді позбавлення волі.

3 іншого боку, навряд чи доцільним є спрощений підхід до сприйняття різних за правовими наслідками та тривалістю реалізації заохочувальних заходів, тим більш їх ототожнення підтверджується самим фактом переліку в одній кримінально-виконавчій нормі. Це не сприятиме посиленню дієвості прогресивної системи в цілому.

Дискусійними залишаються питання віднесення до прогресивної системи таких змін у правовому статусі засудженої особи, які можуть стосуватися незначної кількості засуджених, носити короткочасний характер. Свого часу обґрунтовувалася недоцільність віднесення до прогресивної системи дозволу засудженим на переміщення без конвою (оскільки цей інститут застосовується у виключних випадках і не до всіх засуджених), переведення 3 приміщень камерного типу у звичайні приміщення після відбуття стягнення (це $\epsilon$ поверненням до попередніх умов відбування покарання) [1, с. 29, 30]. За чинним законодавством цей перелік поповнився наданням права окремим категоріям жінок мешкати за межами установи (ст. 142 КВК).

Законодавець прискіпливо віднісся до регламентації підстав надання засудженим жінкам права проживати за межами виправної колонії на час їх звільнення від роботи у зв'язку з вагітністю і пологами, до досягнення дитиною трьох років. Матеріальною підставою $\epsilon$ сумлінне ставлення до праці (якщо жінка працює), дотримання вимог режиму. Отже, вимагається, щоб жінка належно поводилася. Формальною підставою 
$\epsilon$ настання суто демографічних чинників, пов'язаних із терміном вагітності, віком дитини. Підставою для скасування цього права може стати систематичне або ж злісне порушення встановлених правил поведінки. У даному випадку не йдеться про переведення на поліпшені умови, хоча вимагається сумлінне ставлення до праці та дотримання вимог режиму. Зміни у правовому статусі настають за наявності матеріальних підстав (сумлінність поведінки та ставлення до праці), певних соціально-демографічних підстав (стан вагітності та вік дитини). Доцільність суттєвого пом'якшення обсягу правообмежень зумовлюється самим фактом мешкання за межами установи, а отже, необхідністю здійснення життєдіяльності в умовах вільного поводження, але під наглядом адміністрації установи. Отже, фактор стимулювання в набутті права мешкати за межами виправної установи - в наявності. До того ж ці зміни безпосередньо пов'язані як із поведінкою в межах установи (як підстави для надання такого права), так і за їі межами (як підстави для подовження чи скасування такого права). Відповідно, є підстави розглядати цей інститут у якості складової частини однієї із форм прогресивної системи виконання покарання - зміни умов тримання засудженого в межах однієї виправної установи. Проте з набуттям чинності ст. 83 КК, що передбачає можливість звільнення від відбування покарання у вигляді позбавлення волі засуджених жінок, які $є$ вагітними, та жінок, які мають дитину до трьох років, цей інститут практично не застосовується.

Вважалося, що такий підхід значно поширює тлумачення прогресивної системи, призводить до ототожнення 3 нею будь-яких змін, які відбуваються в триманні засуджених [1, с. 29, 30]. Ні в якому разі. Розмежувальним чинником будь-яких змін і таких змін, як відтворення прогресивної системи, має стити вимога щодо поведінки засудженого, не обов'язково досягнення певного ступеня виправлення. І про це свідчить різна термінологія чинного кримінального законодавства в частині визначення вимог щодо поведінки засудженого (належна поведінка, сумлінна поведінка, стає на шлях виправлення тощо). Сучасне законодавство посилює актуальність даного питання, оскільки таких кримінально-виконавчих інститутів, які значно поліпшують правовий стан засудженого, проте не вимагають досягнення певного ступеня виправлення, побільшало.

Наступною формою, яка беззаперечно визнавалася однією з головних серед усіх елементів прогресивної системи, були зміни в порядку утримання засуджених під час відбування ними покарання у вигляді позбавлення волі шляхом переведення з однієї установи до іншої, що здійснювалося також на підставі оцінки поведінки засудженого, ступеня його виправлення (або ж, навпаки, ступеня його соціальної занедбаності) і тягнуло за собою суттєве пом'якшення або ж посилення суворості режимних вимог. Виходячи з останнього, значення та роль цієї форми у процесі виправлення засудженої особи $є$ беззаперечною.

Проте порівняно зі змінами умов тримання засуджених в межах однієї установи ця форма за специфічності свого впливу на психофізичний стан засудженої особи $\epsilon$ більш складною і навіть суперечливою. Адже оцінка ii дієвості впливу на ефективність виправного процесу, а отже, можливостей досягнення максимальних результатів у більш оптимальні терміни має здійснюва- тися більш комплексно, поглиблено, з урахуванням усіх чинників (як позитивного, так і негативного характеру).

Сам факт суттєвого пом'якшення правового стану засудженої особи як результат змін у поводженні засудженої особи безумовно справляє стимулююче значення і цим зумовлює відповідність цієї форми сутності прогресивної системи. 3 іншого боку, слід враховувати і негативні властивості цієї форми. Це переривання виховного процесу, який здійснювався за тих умов та порядку, до яких засуджений пристосувався з перших днів перебування в ізоляції, де умови ізоляції (певні режимні вимоги, нагляд, контроль, посилений виховний вплив) теж спрацьовували в необхідному для виховання напрямку. До того ж засуджений призвичаївся до певного оточення, склалися певні відносини як із засудженими, так і з адміністрацією установи, він віднайшов своє місце у тюремній ієрархії (субкультурі) відповідно до своїх цінностей, нахилів та спрямувань.

Переведення ж до іншої установи має все змінити. І ці зміни слід сприймати не лише як зміни правового статусу, обсягу правообмежень засудженої особи (задля чого вони і відбуваються) - це зміни всієї системи життєдіяльності цієї особи.

Цей аспект особливо відчутно давав про себе знати із часів чинності попереднього виправно-трудового кодексу України, відповідно до якого дана форма прогресивної системи виконання та відбування покарання у вигляді позбавлення волі реалізовувалася шляхом переведення з виправної колонії різного виду режиму (загального, посиленого, суворого) до колонії-поселення, де засуджені практично мешкали вільно, в оточенні місцевого населення. Або ж, навпаки, - до в'язниці (в разі системного злісного поводження), що призводило до суворої ізоляції в камерах. I ця суттєва різниця в умовах та порядку відбування покарання в подальшому по-різному впливала на засуджених, до яких застосовувалася дана форма прогресивної системи [2; 4].

Зокрема, факт переведення засуджених до колонії поселення поширював доступ до раніше заборонених в обігу предметів та речей (алкогольних напоїв, наркотичних речовин, грошей тощо), надавав можливість спілкуватися із представниками протилежної статті, посилював значення самоконтролю власної поведінки. I не всі засуджені, які твердо стали на шлях виправлення, змогли подовжити процес виправлення до свого завершення. Зокрема, вивчення науковцями особливостей рецидивної злочинності серед жінок, переведених до колонії-поселення, кількості та передумов вчинення ними втеч надала підстави дійти висновку щодо того, що значна частина жінок не була готовою до подовження відбування покарання в таких напіввільних умовах, де на перше місце виходить спроможність особи визначати межі своєї власної поведінки [4, с. 48].

Наступний приклад оцінки руйнівного впливу переведення засуджених за злісні порушення вимог режиму (теоретично навіть за умови наявності трьох незначних правопорушень) на підставі ст. 47 ВТК на тюремне ув'язнення для подальшого відбування покарання у вигляді позбавлення волі ми також розглянемо стосовно засуджених жінок. Сталою тенденцією наукових досліджень цього питання $\epsilon$ те, що тривалий час доводилася недоцільність зміни умов у такий спосіб, оскільки в кожній жіночій установі існували можли- 
вості для застосування доволі суворих стягнень у разі вчинення системи правопорушень - переведення до приміщення камерного типу. За злісну ж непокору адміністрації установи мала наставати кримінальна відповідальність (ст. 391 КК) [8, с. 223].

Зазначені нами негативні чинники застосування змін умов тримання засуджених шляхом переведення $з$ однієї установи до іншої надали підстави Ю.М. Ткачевському, який безпосередньо досліджував проблеми прогресивної системи виконання покарання, іiі співвідношення з різними видами звільнення від подальшого відбування покарання у вигляді позбавлення волі за чинності ВТК 1970 р., дійти висновку, що з точки зору кримінально-виконавчої педагогіки найбільш ефективним $є$ безперервний виховний процес, який здійснюється певним колективом вихователів однієї установи. Лише за таких умов $€$ можливість більш досконало вивчити засуджену особу, спостерігати динаміку змін ії властивостей, попереджати прояви негативної поведінки. Вчений вважав, що зміна місця перебування впливає негативно на психічний стан, інтереси, поведінку засудженого. На справедливу думку вченого, саме такі переведення пов'язані із суттєвими змінами умов відбування покарання, що і $\epsilon$ характерною властивістю прогресивної системи виконання покарання [12, с. 29].

Зміст положень чинного кримінально-виконавчого законодавства станом на сьогодні доводить те, що оцінка цієї форми реалізації прогресивної системи набула суттєвих позитивних особливостей із точки зору суттєвого пом'якшення режимних відмінностей між кримінально-виконавчими установами закритого типу. Реформування кримінально-виконавчого законодавства відбувається в напрямку поширення базового (початкового) правового статусу засудженої особи, яка перебуває в ізоляції, з дотриманням принципу: все, що не суперечить, не перебуває у конфлікті із фактом позбавлення волі - дозволити. У підсумку це призвело до незначних відмінностей в обсязі правообмежень (про що більш конкретно - в наступному розділі). Зазначене більшою мірою відноситься до змін у бік погіршення правового стану і стосується, наприклад, переведення з колонії середнього рівня до установи максимального рівня безпеки (ст. $101 \mathrm{KBK).}$

Проте значення змін у бік покращення правового стану продовжує здійснювати суттєву стимулюючу роль, якщо враховувати той обсяг додаткових прав (пільг, можливостей), які засуджений отримає під час його переведення, наприклад, із виправної установи мінімального рівня безпеки із загальними умовами тримання, колонії середнього рівня безпеки до виправної колонії мінімального рівня безпеки з полегшеними умовами тримання.

Тож, безумовно, ця форма реалізації прогресивної системи $є$ доволі важливою і потребує подальшого свого вдосконалення в напрямку посилення стимулюючого значення та нейтралізації тих негативних чинників, які об'єктивно та закономірно супроводжують факт переривання процесу вивчення особи, формування ії нових властивостей, отже, виховного процесу в цілому. $\epsilon$ підстави сподіватися на те, що сам факт суттєвого покращення життя засудженої особи, можливість поновлення зв'язків із позитивним соціальним оточенням спрацюють на завершення виправлення та ресоціалізації.
Підсумовуючи зазначене, слід підкреслити наступне. Історично саме з такою формою прогресивної системи, як зміна утримання засуджених у межах однієї установи, пов'язувалися їі зміст та сутність. В окремих випадках цю форму навіть ототожнювали із прогресивною системою як такою. Сприяє такому підходу той факт, що через інститут зміни умов утримання засуджених в межах однієї установи здійснюється лише узагальнене сприйняття того, що в дійсності відбувається із засудженими. Проте змістовне та сутнісне наповнення цієї форми, механізм (інструментарій) іï реалізації, позитивні та негативні аспекти законодавчих формулювань (суперечливість та недосконалість) відтворюються в конкретних елементах цього інституту. Адже він має свою підсистему, елементи більш нижчого рівня, які вирізняються певною специфічністю змісту правових положень та послідовністю їхньої реалізації. Насамперед, найважливіші властивості прогресивної системи відтворюються в порядку та умовах розміщення засуджених в певних дільницях однієї установи, підставах для переведення із однієї дільниці в іншу (як у бік поліпшення правового стану, так і його погіршення). І кожна із цих дільниць відіграє свою роль у системі стимулювання: дільниця ресоціалізації у формуванні бажання скоротити терміни перебування в ізоляції; започаткуванні дій (перших кроків) щодо поетапної реалізації запланованого; дільниця соціальної реабілітації - у закріпленні в умовах мешкання за межами установи, але під наглядом та контролем адміністрації результатів виправлення та повернення навичок вільного життя, спілкування із громадськістю; посиленого контролю - в наявності потенційної погрози посилення примусу у відповідь на неналежну поведінку, порушення правил безпеки.

Як елемент (складова частина) розглядуваної форми прогресивної системи завжди розглядалися поліпшені умови тримання, які в даному випадку полягають у визначенні їх як конкретного заохочувального заходу, що застосовується за наявності певних матеріальних та формальних підстав. Аналіз суто теоретичної складової даного інституту доводить сталість окремих проблем, які суттєво впливають на сприйняття поліпшених умов як дієвого стимулюючого заходу: не чіткість та суперечливість підстав його застосування; не дотримання закономірностей співвідношення $з$ іншими елементами прогресивної системи. Що зумовлює доцільність його подальшого більш поглибленого дослідження, з'ясування напрямків реформування щодо посилення його стимулюючих властивостей, визначення місця серед інших інститутів прогресивної системи.

Окремою підсистемою зміни умов тримання засуджених у межах однієї установи $\epsilon$ інститут заходів заохочення, передбачений ст. 130 КВК. Саме тенденції реформування цього суто кримінально-виконавчого інституту доводять відсутність єдиного бачення щодо: розуміння співвідношення таких категорій, як «заохочувальна система» кримінально-виконавчого права та елементи цієї системи; критеріїв розмежування між окремими заходами (пільгами) разового застосування та цілими заохочувальними інститутами (наприклад, поліпшеними умовами); важливості дотримання взаємозв'язку та поступовості у їхньому застосуванні, а відповідно, і визначенні підстав для цього тощо. Тому 
і спостерігалися доволі суттєві зміни в частині переліку та характеру цих заходів. Певний час до них відносилися умовно-дострокове звільнення та заміна покарання на більш м'яке. Потім законодавець виключив їх із цього переліку, але доповнив його поліпшеними умовами, окремими пільгами, які стосуються лише порядку перебування в окремих дільницях. Суперечливість інституту, визначеного у ст. 130 КВК, полягає в тому, що до нього віднесені як разові заходи заохочення, які стосуються усіх засуджених, не залежать від терміну відбування покарання, так і ті, що є складовою частиною правового статусу перебування в конкретній дільниці. Недосконалість даного інституту відтворюється також у порушенні системи взаємозв'язку між різними заохочувальними заходами, що $\epsilon$ елементами прогресивної системи, через невідповідність підстав їхнього застосування.

Зміна умов тримання засуджених шляхом переведення до іншої установи (як і попередня форма прогресивної системи) історично вважалася головним, найтиповішим їі виявом. Тож питання щодо доцільності віднесення іiі до форм прогресивної системи не постоїть. Проте саме ця форма історично розглядалася як така, що об'єктивно (окрім стимулюючого впливу) містила в собі потенційні негативні властивості, які зумовлювалися психологічними закономірностями впливу на особу суттєвих змін його соціального статусу та умов його життєдіяльності. Особливістю сучасного реформування даної форми прогресивної системи $\epsilon$ те, що суттєве поліпшення правового статусу засуджених (у частині коштів, побачень, листування, телефонних розмов, Інтернету, одягу, харчування тощо) безвідносно до терміну відбутого строку покарання та видів режиму.

Висновки. У підсумку значно невілюються відмінності у правосуб'єктності засуджених, які перебувають у кримінально-виконавчих установах закритого типу різного рівня безпеки, вже на початковому етапі перебування в ізоляції. А факт зрівняння у правовому статусі засуджених, які перебувають у дільниці соціальної реабілітації, і тих, кого переводять до виправної установи мінімального рівня безпеки з полегшеними умовами тримання, - взагалі доводить те, що максимальне поліпшення правового статусу $\epsilon$ практично можливим у межах однієї установи, не порушуючи ті відносини, які склалися між засудженою особою і іï оточенням та адміністрацією. Зазначений напрям має бути подовжений до максимального виконання міжнародно-правових зобов'язань у частині дотримання міжнародно-правових стандартів, дотримання природних прав людини, навіть в умовах суворої ізоляції ії від суспільства. Це, у свою чергу, передбачає переоцінку значення та місця розглядуваної форми в прогресивній системі, оскільки за рахунок дільниць, приміщень камерного типу буде можливість для реалізації повного циклу зміни умов тримання засуджених під час їх відбування покарання у вигляді позбавлення волі, але в межах однієї установи.

\section{Література}

1. Бажанов О.И. Вопросы совершенствования прогрессивной системы отбывания наказания. Труды Всесоюзного научно-исследовательского института МВД СCCP. № 30. М., 1974. С. 27-37.

2. Волошин Н.И. Осужденные, отбывающие наказания в тюрьмах. Вып. 6. Москва : ВНИИ МВД СССР, 1972. 35 с.

3. Галінський О.І. Особливості застосування заходів заохочення до жінок, засуджених до позбавлення волі. Південноукраїнський правничий часопис. № 1. 2006. С. 22-25.

4. Дутов М.А. Правовые и организационные вопросы исполнения наказания и перевоспитания женщин, переведенных в исправительно-трудовые колонии-поселения: Учебное пособие. Рязань : МВД СССР, 1981. 53 с.

5. Конопельский В.Я. Переведення на поліпшені умови утримання засуджених до позбавлення волі: окремі теоретичні та правові аспекти. Південноукраїнський правничий часопис. № 4, 2009. С. 54-57.

6. Кревсун О.М. Прогресивна система виконання покарання у вигляді позбавлення волі на певний строк у виправних колоніях : автореф. дис. на здобуття наук. ступ. канд. юрид. наук : 12.00.08. Харків : ХНУВС, 2016. 20 с.

7. Кримінально-виконавче право України : підручник / О.М. Джужа, І.Г. Богатирьов, О.Г. Колб, В.В. Василевич та ін. ; за заг. ред. докт. Юрид. наук, проф., О.М. Джужи. Київ : Атіка, 2010. 752 с.

8. Меркулова В.О. Жінка як суб'єкт кримінальної відповідальності: Монографія. Вид. 2-ге. Одеса : НДРВВ ОЮІ НУВC, 2003. 281 c.

9. Меркулова В.О. Поліпшені умови утримання в установах по виконанню покарання у вигляді позбавлення волі: тенденції законодавчого регулювання. Південноукраїнський правничий часопис. № 2, 2014. С. 14-18.

10. Резніченко Г.С. Особливості виконання і відбування покарання у вигляді позбавлення волі щодо засуджених жінок : монографія. Одеса : ОДУВС, 2009. 173 с.

11. Стручков Н.А. Уголовная ответственность и ее реализация в борьбе с преступностью: монография. Саратов : Изд-во Саратовского ун-та, 1978. 288 с.

12. Ткачевский Ю.М. Замена одного наказания другим в процессе его исполнения. Вестник Московского универcumema. Сер. 11. Право. 2006. № 2. С. 20-34.

13. Якимович Ю.К. Изменение условий содержания осужденных в пределах одного исправительно-трудового учреждения (Вопросы совершенствования правового регулирования). Правовые вопросы борьбы с преступностью. Томск, 1982. С. 83-90.

Гритенко О. А., кандидат юридичних наук, доцент, професор кафедри кримінального права та кримінології Одеського державного університету внутрішніх справ 